\title{
A Zhong-Yong Perspective on Balancing the Top-down and Bottom-up Processes in Strategy-making
}

\author{
Li, Xin; Andersen, Torben Juul; Hallin, Carina Antonia
}

\author{
Document Version \\ Accepted author manuscript \\ Published in: \\ Cross Cultural and Strategic Management
}

DOI:

10.1108/CCSM-01-2019-0018

Publication date:

2019

License

Unspecified

Citation for published version (APA):

Li, X., Andersen, T. J., \& Hallin, C. A. (2019). A Zhong-Yong Perspective on Balancing the Top-down and Bottom-up Processes in Strategy-making. Cross Cultural and Strategic Management, 26(3), 313-336. https://doi.org/10.1108/CCSM-01-2019-0018

Link to publication in CBS Research Portal

\section{General rights}

Copyright and moral rights for the publications made accessible in the public portal are retained by the authors and/or other copyright owners and it is a condition of accessing publications that users recognise and abide by the legal requirements associated with these rights.

\section{Take down policy}

If you believe that this document breaches copyright please contact us (research.lib@cbs.dk) providing details, and we will remove access to the work immediately and investigate your claim.

Download date: 26. Apr. 2023

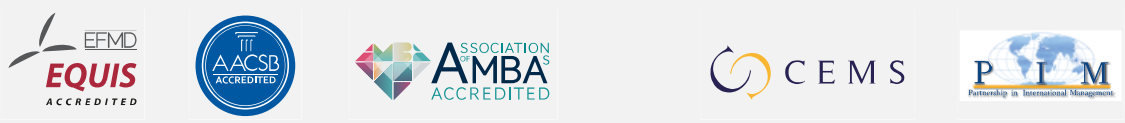




\title{
A Zhong-Yong Perspective on Balancing the Top-down and Bottom-up Processes in Strategy-making. Cross Cultural and Strategic Management
}

\author{
Kin Li, Torben Juul Andersen, and Carina Antonia Hallin
}

Journal article (Accepted manuscript*)

\section{Please cite this article as:}

Li, X., Andersen, T. J., \& Hallin, C. A. (2019). A Zhong-Yong Perspective on Balancing the Top-down and Bottom-up Processes in Strategy-making. Cross Cultural and Strategic Management, 26(3), 313-336. https://doi.org/10.1108/CCSM-01-2019-0018

\section{DOI: https://doi.org/10.1108/CCSM-01-2019-0018}

This article is (0) Emerald Group Publishing and permission has been granted for this version to appear here: https://research.cbs.dk/en/publications/a-izhong-yongi-perspective-on-balancing-the-top-down-and-bottom$\underline{u}$

Emerald does not grant permission for this article to be further copied/distributed or hosted elsewhere without the express permission from Emerald Group Publishing Limited.

* This version of the article has been accepted for publication and undergone full peer review but has not been through the copyediting, typesetting, pagination and proofreading process, which may lead to differences between this version and the publisher's final version AKA Version of Record. 


\title{
A Zhong-Yong Perspective on Balancing the Top-Down and Bottom-Up Processes in Strategy-Making
}

\author{
Xin Li (xl.egb@cbs.dk) \\ Torben Juul Andersen (tja.egb@cbs.dk) \\ Carina Antonia Hallin (cah.egb@cbs.dk) \\ Copenhagen Business School, Denmark \\ Accepted for publication in \\ Cross-Cultural \& Strategic Management \\ on March 20, 2019
}

\begin{abstract}
Purpose: This paper proposes an alternative perspective on Zhong-Yong (中庸) that is different from the notion of 'Yin-Yang balancing' and applies it to understand the issue of balancing the top-down and bottom-up processes in strategy-making.

Design/methodology/approach: We adopt a 'West meets East' mindset and approach to developing an alternative perspective on Zhong-Yong, and then apply this perspective to understand the issue of balancing the top-down and bottom-up processes in strategy-making. There are three steps in the process of developing the alternative perspective. First, we argue that the essence of 'Yin-Yang balancing' is a ratio-based solution to paradoxical balancing, which is in fact equivalent to Aristotle's doctrine of the mean and compatible with some Western management scholars' approaches to solving paradox. Second, we identify a different generic solution to paradoxical balancing implicit in the Western management literature. Third, we find in the original text of Zhong-Yong equivalent ideas to the identified different generic solution and then propose an alternative perspective on Zhong-Yong that is fundamentally different from the notion of 'Yin-Yang balancing'.
\end{abstract}

Findings: Applied to the issue of balancing the top-down and bottom-up processes in strategymaking, the new perspective on Zhong-Yong provides us with the following prescriptive insights from the life-wisdom of Eastern philosophy:

First, top management (e.g., Shun as the sage-king) must listen to various views and opinions also from employees and low-level managers at the bottom of the organization to be better informed about complex issues.

Second, top management must analyze the diverse elements of the various views and opinions they collect and synthesize by taking the good from the bad to find smarter solutions and make decisions with better outcomes.

Third, abiding by a set of (more or less) cohesive values help top managers be open and receptive to information and insights from low-level organizational members and enhancing unbiased information. 
Research limitations/implications: This paper is a mainly a theoretical perspective. Empirical work is needed to test the prescriptions offered in this paper.

Practical implications: Practitioners may learn new perspectives from ancient Chinese philosophies on how to balance.

Originality/value: This paper applies a new perspective on Zhong-Yong to an important paradox in strategic management.

Keywords: Paradox, Yin-Yang, Zhong-Yong, balancing, strategy-making

Acknowledgement: The research was partially supported by the Carlsberg Foundation's Postdoctoral Fellowship in Denmark grant (CF15-0270), a project granted to the first author. 


\section{INTRODUCTION}

The mainstream management research has been largely West-based and -dominated. Some scholars argue that theories developed from Western perspectives may not be suitable for or applicable to other parts of the world due to the cultural and institutional differences between the West and the East in particular and the non-Western world in general. Such an increasing awareness of the existence of the differences has given rise to the indigenous management research movement and subsequently the 'West meets East' discourse.

The indigenous social science research movement started first in psychology and later spread into the management field. According to Jahoda (2016: 170), there are two major causes of the rise of the indigenous psychology movement with its beginning more than half a century ago in the Philippines and Taiwan, one being 'the shift in power relations away from Europe and America and towards Asian countries' and ' $[t]$ he consequent rise in national feeling and selfconfidence', and the other being the perception that 'western psychology is not appropriate for Asian and other cultures since it was developed in the particular socio-cultural environment of America, and does not correspond to their needs' (ibid.).

If the mainstream psychological and behavioral sciences are 'based on samples drawn entirely from Western, Educated, Industrialized, Rich, and Democratic (WEIRD) societies' (Henrich, Heine and Noranyazan, 2010a: 61), then it is natural to doubt the applicability of the Western social science knowledge to the rest of the world because 'most people [in the world] are not WEIRD' (Henrich, Heine and Noranyazan, 2010b: 29). As WEIRD samples are 'so unusual', there might be 'the existence - or potential existence - of broad-ranging variation among populations' in not only psychology but also behavior (Henrich, Heine and Noranyazan, 2010a: 122). Such a belief provides a rational justification for indigenous management research.

While the existence of West-East differences is explicitly used to justify the indigenous management in China (Leung, 2012; Li, Leung, Chen and Luo, 2012) and Asia (Li, Sekiguchi and Zhou, 2016), it is not difficult to detect the national pride and self-confidence behind the arguments for the need of indigenous management research in China in particular and Asia in general.

Chinese indigenous management research has generated many insights that either complement or challenge (or both) the Western perspectives, demonstrating the value of the Chinese/Eastern perspectives. Some examples include Fang's (2012) new perspective on culture based on Chinese Yin-Yang philosophy, Jing and Van de Ven's (2014) new model of organizational change based on Chinese notion of shi meaning momentum, Zhang, Waldman, Han and Li's (2015) study of the paradoxical leader behaviors in people management in China, and Zheng, Li, Harris and Liao's (2017) study of subordinate-supervisor relationship based on Chinese notion of moqi meaning a tacit understanding of another person's expectations and intentions.

The belief that contrasting or/and combining Western and Eastern perspectives can generate better understanding of management issues has led to the emergence of the 'West meets East' discourse in recent years (Barkema et al., 2015; Chen \& Miller, 2010, 2011). For instance, in 2010, the Academy of Management adopted 'West meets East: Enlightening, balancing, and transcending' as the theme for its 2011 annual conference. Subsequently, in 2011 Academy of Management Journal made a Special Research Forum call for paper with the theme 'West meets East: New concepts and theories' that was published in 2015. In 2016, Journal of Management Studies also announced a Special Issue call for paper with the theme 'Connecting Eastern \& 
Western perspectives on management: Translating practices across organizations, institutions and geographies'.

Unfortunately, some Chinese scholars have adopted biased views when comparing and contrasting Western and Chinese perspectives. For example, Some Chinese contrast Western and Chinese thought as either/or vs. both/and perspectives (Chen, 2002, 2008, 2016; Chen and Miller, 2010, 2011), implying that Westerners have no or little holistic (both/and) thinking that is needed for understanding complex issues. What's more assertive is the view that Chinese way of thinking, labelled as 'Yin-Yang balancing', is superior to the Western way of thinking in dealing with paradox that is deemed as the most complex or challenging issue in the management literature. More specifically, 'Yin-Yang balancing' is claimed to be superior to the Western ambidexterity approach to paradox in particular and to the Western analytical and dialectical thinking in general (Li, P., 2014, 2016).

We are concerned about the Chinese exceptionalism and enthnocentrism (as critiqued by Li, X., 2016; Li and Ma, forthcoming; Peng, 2005) embedded in such biased views. We think both exceptionalism and enthnocentrism are dangerous (Li, X., 2014, 2016) for the healthy development of management research in China in particular and can do disservice to the global community of management scholarship in general.

While we acknowledge that there exist many differences between the Western and Eastern perspectives, we believe that there are also many similarities, visible or latent. We worry that some people tend to neglect or downplay the similarities while focusing on or exaggerating the differences.

Our purpose in writing the present paper is two-fold. First, we counter-argue aforementioned Chinese-superiority assertions by demonstrating that, on the one hand, the so-claimed inferior ambidexterity approach is not only compatible with some Chinese sayings and practices inspired by the Yin-Yang thinking but also very valuable for some paradoxical situations; and on the other hand, the so-claimed superior 'Yin-Yang balancing' solution to paradox is in fact equivalent to Aristotle's doctrine of the mean and compatible with some Western management scholars' approaches to solving paradox. Second, we argue that we can gain better understanding of paradox by connecting Eastern and Western perspectives, that is, to develop new ideas by learning from both perspectives. We support this argument by an illustrative case (Siggelkow, 2007), namely, developing an alternative generic solution to paradoxical balancing to the commonly used solution (i.e., proportional integration of opposites), for understanding the paradoxical nature of top-down and bottom-up processes in strategy-making.

In the following two sections, we explicate abovementioned two arguments, i.e., the compatibility between Western and Chinese perspectives on paradox, and the feasibility of developing better understanding of paradox by connecting Western and Chinese perspectives.

\section{THE COMPATIBILITY BETWEEN WESTERN AND CHINESE PERSPECTIVES}

While it is common to consider Western thinking as largely 'either/or' based in contrast to the Chinese 'both/and' philosophy, it is clearly manifested that Westerners also think dialectically (Li X., 2014). Western philosophy has a long tradition of dialectical thinking going back to Ancient Greek thinkers such as Heraclitus, Zeno, and Aristotle, followed by many later European scholars including Kant, Fichte, Schelling, Hegel, Marx, Engels, Nietzsche, and Adorno, among others. 
The organizational and management scholarship in the West has moved beyond the one-size-fitsall approach to the contingency thinking to the paradox perspective (Smith \& Lewis, 2011). The earlier organization and management theorists tended to prescribe one best way to manage organization with a simplistic either/or approach to organizational tension, i.e., choosing either A or its opposite $-\mathrm{A}$ once for all. The contingency theorists adopt a more sophisticated either/or thinking by asking under what conditions one should choose either A or its opposite $-\mathrm{A}$. The paradox researchers embrace both/and thinking and ask how to engage or integrate $\mathrm{A}$ and its opposite -A simultaneously.

\section{The Western Ambidexterity and Strategy Thinking}

Since the publication of Peters and Waterman's (1982) best-selling book In Search of Excellence and Van de Ven's (1983) review of it, strategic management and organizational scholars have become increasingly interested in the issue of strategic and organizational paradoxes (e.g., Amason, 1996; cf. Bartunek and Rynes, 2014; Bobko, 1985; Cameron, 1986; Clegg, 2002; De Wit and Meyer, 2001; Demb and Neubauer, 1992; Denison, Hooijberg and Quinn, 1995; Dodd and Favaro, 2006; Eisenhardt, 2000; Evans, 2000; Farjoun, 2010; Handy, 1994; Koot, Sabelis and Ybema, 1996; Lewis, 2000; Miller, 1990; Poole and Van de Ven, 1989; Quinn and Cameron, 1988; Seo and Creed, 2002; Smith, 2014; Smith and Berg, 1987; Smith and Lewis, 2011; Sundaramurthy and Lewis, 2003). Organizational paradox has been conceived as observations where 'two apparently contradictory elements are seen as present or operating at the same time' (Quinn and Cameron, 1988: 290) or 'contradictory strategic and organizational demands on firms' (Smith and Tushman, 2005: 522) that need to be attended 'for long-term organizational success' (Smith, Binns and Tushman, 2010: 450). This is distinct from logical paradox ${ }^{1}$ defined as 'an argument with seemingly true premises, apparently correct reasoning, and an obviously false or contradictory conclusion' (Cuonzo, 2014: 111-112; cf. Quine, 1976).

Smith and Lewis (2011: 382) define paradox as 'contradictory yet interrelated elements that exist simultaneously and persist over time'. Recently, Schad, Lewis, Raisch and Smith (2016: 10) changed that definition into a simpler version, i.e., 'persistent contradiction between interdependent elements'. Such a definition identifies two core characteristics of paradox (Lewis, 2000), contradiction (underlying tensions between two opposites) and interdependence (the need to embrace two opposites simultaneously. Slaatte (1986: 4) well captures the essence of paradox, namely, 'two opposing thoughts or propositions...however contradictory, are equally necessary to convey a more ... provocative insight into truth than either factor in its own right'.

Peters \& Waterman (1982) and Mitroff (1983) contend that paradox is inherent in the nature of organization. For example, although small is beautiful most organizations aspire to get big; for the sake of growth organizations often diversify, but to be successful they need to focus on their core businesses; and organizations hire a heterogeneous work force but often want homogeneous values. Stroh \& Miller (1994: 30) point out that 'life is full of contradictions that we must integrate'. Hardy (1994) claims that we are living in the age of paradox. Peters \& Waterman (1982: 100) show that 'the excellent companies have learned how to manage paradox', which is echoed by Evans (2000). However, managing organizational paradox is not easy because it typically imposes opposite demands, such as, change vs. stability (Farjoun, 2010; Leana and Barry, 2000), centralization vs. decentralization (Perrow, 1977; Witesman and Wise, 2009), and

\footnotetext{
${ }^{1}$ There are yet other types of paradox different from organizational paradox, such as, linguistic and epistemic paradoxes (Cuonzo, 2014; Lado et al., 2006; Poole and Van de Ven, 1989).
} 
localization vs. globalization (Bartlett and Ghoshal, 1989). Each of these opposing demands seems valid and necessary but "when juxtaposed, they present a puzzle" (Poole and Van de Ven, 1989: 565).

The ambidexterity literature started largely independent of the paradox literature. Tushman and O'Reilly (1996), who made the notion of ambidexterity popular, trace the origin of the ambidexterity literature to Duncan's (1976) analysis of building an ambidextrous organization by designing dual structures for innovation. While Duncan (1976) does not mention paradox, he does talk about dilemma and conflict, which the paradox literature often refers to. Tushman and O'Reilly (1996: 24) link ambidexterity to paradox by arguing that "ambidextrous organizations are needed if the success paradox [i.e., success often precedes failure] is to be overcome". Duncan's (1976) work on designing dual structures for innovation inspired the so-called structural approach to organizational ambidexterity (Tushman and O'Reilly, 1996; O'Reilly and Tushman, 2013) whereby two opposite tasks undertaken simultaneously are separated, e.g., by time (temporal separation) or place (spatial separation. The structural ambidexterity is normally achieved through top-down organizational design where top management decides how to separate opposing tasks that must be undertaken by the organization.

Recognizing the importance of simultaneously balancing seemingly contradictory tensions, Gibson and Birkinshaw (2004) propose an alternative approach to organizational ambidexterity, i.e., contextual ambidexterity. They argue, contextual ambidexterity differs markedly from structural ambidexterity because the former is achieved not through the creation of dual structures but by building a supportive context (i.e., a set of processes or systems) that enable and encourage individual members of the organization to make their own decision on how to divide their time between conflicting or opposite demands. In our view, the contextual and structural distinction in the ambidexterity literature may not be that important for two reasons. One, the contextual ambidexterity ultimately relies on separation (dividing one's time between opposite tasks) as the structural ambidexterity does. The other, the two types of ambidexterity often need to be used simultaneously as Duncan (1976: 184, italic in original) stresses that 'in order to utilize this dual structure for dealing with the two stages of the innovation process, it is necessary to develop a climate in the organization that supports this process and views it as a legitimate part of one's job'.

So, the ambidexterity approach is arguably a legitimate, although a particular solution to the fundamental organizational paradox of choosing between optimizing value-creation through economic efficiency and innovating for future strategic renewal. It is a legitimate solution to paradox because, in Poole and Van de Ven's (1989) influential typology of modes of working with paradoxes, two of the four generic solutions that they identify, i.e., clarify levels of analysis and temporally separate the two levels, are in essence equivalent to the ambidexterity approach, i.e., spatial separation and temporal separation respectively. Yet, it is a particular way of approaching paradox. In a sense, the ambidexterity approach can be seen as compatible with the contingency thinking (a more sophisticated either/or thinking), because the ambidexterity thinking relies on the methodology of separation, temporal or spatial, which is either/or in nature. In fact, Robert B. Duncan, the grandfather of the ambidexterity approach, writes his 1976 article with the opening sentence 'This paper will present a contingency model for designing organization for innovation'.

The strategic management literature has grappled with very similar paradoxical challenges of balancing the need for sustainable competitive advantage (measured as excess returns) between 
exploring current market and resource positions while developing those for tomorrow in a changing environment. According to the traditional strategy paradigm, corporate executives develop strategies that fit the environment and structure the organization to match it (e.g., Andrews, 1971; Chandler, 1990). This has been conceptualized as a rational analytical top-down process (Schendel and Hofer, 1979; Chakravarthy, 1982). In contrast, organization theorists have proposed informal decentralized bottom-up processes as the prescriptive approach to deal with turbulent environmental conditions as opposed to formal mechanistic structures (e.g., Achrol, 1997; Daft and Lewin, 1993; Galbraith, 1995; Volberda, 1996). To reconcile this choice between these alternatives, scholars generally recognize that strategy is influenced by simultaneous processes of top-down intent and more immediate bottom-up responses (e.g., Ansoff, 1988; Bower, 1982; Brady and Walsh, 2007; Kim, Sting and Loch, 2014; Mom, Van Den Bosch and Volberda, 2007) expressed as intended and emergent (Mintzberg, 1978; Mintzberg and Waters, 1985), or induced and autonomous strategies (Burgelman and Grove, 1996; 2007).

A number of authors have suggested the presence of different process archetypes across organizations representing alternative strategy-making modes differentiated by their relative emphasis on direct command from the top and more spontaneous initiatives from the bottom (e.g., Bourgeois and Brodwin, 1984; Hart, 1992; Nonaka, 1988). It is also implied that the different strategy-making modes can coexist within the same organization separated by different organizational levels or time-periods contingent upon the specific conditions of the environment, which can change from time to time (Hart, 1992; Hart and Babury, 1994).

For example, Hart (1992) identified five generic strategy-making modes (command, symbolic, rational, transactive, and generative) where the role of top management (top-down) and role of organizational members (bottom-up) are assigned different weights in the strategy-making process. In the extreme typology there is 100 percent emphasis on top-down direction (command) versus 100 percent emphasis on bottom-up initiatives at the other end (generative) whereas the 'middle' typologies exert different percentage splits between the two extreme modes. In an advanced study of resource-committing strategic decisions in Intel, Burgelman and Grove (2007) show how there must be a certain balance between top-down (induced) and bottom-up (autonomous) driven decisions over time with a certain percentage emphasis on either that possibly may hover between 30 and 70 percent dependent on external market conditions.

In short, strategy research displays similar attempts to deal with paradox through spatial separation across hierarchical levels and temporal separation where adherence to alternative strategy-making modes is contingent on the situation influenced by the changing environmental conditions. Yet, the strategy-making literature falls short of providing a nuanced analysis on how to balance the opposite top-down and bottom-up processes and under what organizational contexts this is a viable solution.

\section{The Chinese Yin-Yang and Zhong-Yong Thinking}

Chinese Yin-Yang thinking is at times considered ideal for the ability to deal with paradox. The ambidexterity-related research has been brought into two broad categories of separated and integrated ambidexterity where neither of the two seems to embrace the simultaneous trade-off between conflict (need for separation) or synergy (need for integration) between paradoxical opposites. Therefore, the solutions derived from the ambidexterity literature are said to fail to provide a genuine solution to deal effectively with paradox (Li P., 2014). In contrast, Chinese YinYang thinking is claimed to capture the simultaneous relationships needed between conflicting 
and complementary opposites and provide a real solution to the tensions of paradox. Namely, at the cognitive level the paradoxical opposites should be partially conflicting and complementary while on the behavioral level the paradoxical opposites should be partially separated and integrated.

The notion of 'partial' here is key to understand the essence of the Yin-Yang thinking because, according to Yin-Yang, everything (A) contains in itself its opposite (-A) and therefore the two opposites (A and $-\mathrm{A}$ ) always coexist and interact simultaneously, and the dynamic interaction between the two opposites can gradually transform them into each other. Due to the simultaneous coexistence, dynamic interaction, and gradual transformation, nothing can be said to be either pure A or pure $-\mathrm{A}$, but only a partial A and a partial -A combined (i.e., 'both/and'. This may be taken so far as to claim that 'Yin-Yang balancing' is superior to other cognitive frames and the only one that can fully embrace paradox (Li P., 2014, 2016). However, such a superiority assertion is doubtful for three reasons.

First, the separation perspective of ambidexterity is also visible in Chinese practices that are inspired by or directly derived from Yin-Yang thinking. For example, a popular Chinese saying goes 'fortune and misfortune are mutually dependent' (祸福相倚). The original expression appears in the fifty-eighth section of Tao Te Ching (道德经), which reads “disaster is the avenue of fortune, and fortune is the concealment for disaster. Who would be able to know its ultimate results? As it is, there would never be the normal. But the normal would immediately revert to the deceitful. And the good revert to the sinister." This saying is entirely compatible with the temporal separation of ambidexterity in the sense that the same thing can be fortunate, normal, or good at one time but also disastrous, deceitful, or sinful at another time.

Another Chinese saying goes 'the orange tree in the South turns into lime bushes in the North' (南 橘北枳. The original expression appears in The Spring and Autumn Annals of Master Yan (晏子 春秋), which reads “when orange-trees grow south of the Huai River, they become good orangetrees, but when they are planted north of it they turn into thorny lime bushes. The leaves look alike, but fruitless, for the taste of the fruits is quite different. How can this be? It is because the water and the sail are not the same." This saying is entirely compatible with the spatial separation of ambidexterity in the sense that the same thing can be an orange-tree in one space but a thorny lime bush in another space. As a matter of fact, the Chinese often say 'act in one way at one time or in one place while change to another way at another time or in another place', which can be equated with the temporal and spatial separation embedded in the conceptualization of ambidexterity as well as the proposed strategy-making approaches.

Second, the ambidexterity approach is very valuable for some paradoxical situations, such as the rigor-relevance debate. Many scholars have called for balancing academic rigor and practical relevance in conducting management research (e.g., Bartunek and Rynes, 2014; Kieser, Nicolai and Seidl, 2015) given the criticism that much of the management literature is not relevant to management practice (e.g., Bennis and O'Toole, 2005; Vermeulen, 2005). However, Daft and Lewin (2008): the founding co-editors of Organization Science (OS), after 18 years of journal editing experience, despite their initial commitment to encourage and publish in $O S$ studies that are both rigorous and relevant (Daft and Lewin, 1990), have come to realization, that 'Direct Practical Relevance Was a Nä̈ve Aspiration for $O S$ ' (p. 181) and 'Journals that serve as a source of academic knowledge should have a fundamental mission to publish diverse new ideas of high quality without regard to relevance to the world of practice'. Daft and Lewin's argument is ambidextrous in nature because they acknowledge that 
'Academic relevance and practical relevance serve different subcommunities... The larger academic arena is made up of many journal-based subcommunities, each with its own niche, world view, values, and purpose, and some with more direct links to practitioners (e.g., HBR. The process for how knowledge is created in one subcommunity and appropriated by another subcommunity is ill defined and poorly understood, and deserves much deeper study. However, idea migration does happen and the natural migration of knowledge and selection processes at various levels does eventually create practical outcomes' (p. 181).

Third, the 'Yin-Yang balancing' approach is also entirely compatible with Aristotle's doctrine of the mean as outlined in his Nicomachean Ethics. 'Yin-Yang balancing' is in fact a restricted version of the commonly-understood Confucian principle of Zhong-Yong, which prescribes balance and integration of opposites by avoiding both extremes and choosing a moderate or middle position. It is worth noting that while the word 'Zhong' literally means middle, Zhong-Yong does not imply a fixed middle position between two opposites because Zhong is moderated contingent on the specific circumstances of the situation. The so-called 'Yin-Yang balancing' is a restricted version of Zhong-Yong where the former disallows a precise middle 50:50 position while the latter does not impose such a restriction. The 'Yin-Yang balancing' solution requires that one of the two opposites is a dominant element while the other is a subordinate element and the relative weights of the two opposites change dynamically in combination over time.

According to Gottlieb (2009: 19), Aristotle's doctrine of the mean has three aspects: "First, virtue, like health, is in equilibrium and is produced and preserved by avoiding extremes and hitting the mean; it is self-sustaining. Second, virtue is in a mean 'relative to us'. Third, each virtue is in a mean between two vices, one of excess and one of deficiency." So, Aristotle's mean is not an arithmetic calculation equidistant from two opposed extremes. The mean is "relative to us", which "cannot be determined without close attention to features of the persons to whom such means are relative and the circumstances in which those persons are placed" (Losin, 1987: 332). Such a mean 'relative to us' is equivalent to the Zhong-Yong notion of balancing according to the specific circumstances of the situation. Clearly, Zhong-Yong is highly compatible with Aristotle's doctrine of the mean, and therefore, there appears to be little basis in ascribing this virtue solely to Chinese thinking and asserting the superiority of 'Yin-Yang balancing'.

The "properly balanced ratio" of one of the opposites to the other (Li, P., 2014: 330; Lin, Lu, Li and Liu, 2015; cf. March, 2010: 81) emerges as the important consideration in the 'Yin-Yang balancing' approach, which is a particular interpretation of Zhong-Yong albeit a very predominant one. Here, the essence is to balance the paradoxical opposites by partially or proportionally endorsing each of the two in a 'balanced' position somewhere in between them.

With regard to the exploitation-exploration paradox (March, 1991), the 'Yin-Yang balancing' solution is to allocate resources to partially support both exploitation and exploration, while the choice of ratio of allocation is not fixed but contingent upon specific circumstances $(\mathrm{Li}, \mathrm{Li}$ and Liu, 2012). Such a ratio-based resource allocation solution to balance between exploration and exploitation is also endorsed by Nagji and Tuff (2012) in a Harvard Business Review article. They argue, with supporting evidences, that successful firms normally simultaneously invest in three categories of activities, i.e., core (exploiting existing): adjacent (expanding from existing core into 'new to the company' business), and transformational (exploring breakthroughs and things new to the market. They found, on average, high-performing firms allocate about $70 \%$ of their resources to enhance existing core businesses, $20 \%$ to exploit adjacent opportunities, and $10 \%$ to explore transformational initiatives. But, as they point out, individual firms in different industries may deviate from such a 70:20:10 resource allocation ratio for sound strategic reasons. 
Although such a ratio- or proportion-based approach to balancing between paradoxical opposites is a common understanding of Zhong-Yong, we argue it is not the only way to understand ZhongYong. Judging from the prescribed mechanisms derived from 'Ying-Yang balancing', they are explained by changes in the "ratio of relative sizes" of opposing dynamic processes over time (Li P., 2016). Even though these mechanics are discussed at a high conceptual level, they have a strong resemblance to the more concrete empirically supported 'ratio analyses' pursued in the extant strategy-making literature (e.g., Hart, 1992; Burgelman and Grove, 2007). So, one may question how exactly the high-level principles of 'Ying-Yang balancing' extends beyond what has already been gained from the contributions and insights already uncovered in Western management research.

In the following section, we will discuss a newly discovered and largely neglected understanding of Zhong-Yong that offers an alternative perspective to the ratio-based resource allocation solutions to paradoxical integration.

\section{CONNECTING EASTERN PHILOSOPHY AND WESTERN RESEARCH}

\section{An Alternative Generic Solution to Paradoxical Integration}

In the prior section, we attempted to show the compatibility between Chinese and Western perspectives. Here, we try to demonstrate how this compatibility can enable enhanced learning by connecting Eastern and Western perspectives. As explained, 'Yin-Yang balancing' as a restricted version of Zhong-Yong, is highly compatible with Aristotle's doctrine of the mean as a generic solution to integrating paradoxical opposites by partially or proportionally endorsing each of the two opposites. Such a generic solution often treats each of the opposites as a takenfor-granted entity. In other words, each of the opposites that are to be balanced is treated as a 'black box' without examining its inner structure or mechanism. While in some situations such a ratio-base or proportional combination solution is sufficient, in some other situations it may be insufficient or does not make sense at all. For example, when it comes to how to balance (i.e., integration vs. separation) traditional business and electronic commerce, it is not clear what it means by saying that the two opposite business models should be $n$ percent integrated and (100$n$ ) percent separated. In a Harvard Business Review article titled 'Get the right mix of bricks \& clicks', Gulati and Garino (1999) present a different solution from the ratio-based generic solution. They do not treat the bricks (i.e., traditional business) and clicks (i.e., electronic commerce) models as 'black boxes', but dissect them into several dimensions, i.e., brand, top management team, operations, and equity ownership, and then show different companies adopt different degrees of integration for those different dimensions.

As Gulati and Garino's (1999) work was published in a practitioner-oriented journal, it is not in particularly concerned about theory building. Yet, their work provides an important inspiration for us in search for an alternative generic solution to paradoxical integration. We were motivated to reexamine the original text of Zhong-Yong to see whether there is any equivalent or similar ideas in the text. With such an inspiration, we did find compatible ideas in the text, which enabled us to develop an alternative interpretation of Zhong-Yong, the essence of which is said to be 'analysis plus synthesis' (Li, 2018: 375). In Gulati and Garino's (1999) work, the 'analysis' part is their dissection of the business model into several dimensions and the 'synthesis' part is their finding that under different circumstances companies may adopt different degrees of integration. 
Zhong-Yong is considered the last and most important of The Four Books of Confucianism. While it is referred to as a book, it is actually a short article with only 3,544 Chinese characters that originally appeared as a chapter in The Liji (Book of Rites, 礼记) that records the writings of Confucius' disciples and other Confucian scholars of the Warring States Period (475 B.C. - 221 B.C.). Zhong Young captures human wisdom derived from experiential insights cumulated over centuries and often paraphrased in prose that requires scholarly interpretation. Hence, it is not exact in its meaning and prescription, but contains gems of wisdom to be extracted by the studied reader. Hence, the potential value, and also potential misguidance will depend on useful interpretations of the wise words.

The word 'zhong' means moderate or middle and the word 'yong' means constant or consistent. The Chinese character of zhong only appears 24 times in the text of Zhong-Yong and among the 24 appearances, only four of them directly explain what Zhong-Yong means or how Zhong-Yong balancing can be accomplished.

The first one is the sentence “喜怒哀乐之未发谓之中. 发而皆中节谓之和”, which can be translated as 'when there are no stirrings of pleasure, anger, sorrow, or joy, one can be said to be in the state of zhong. When these feelings are aroused, and one keeps them in due measure and degree, then one can be said to be in the state of harmony'. While the common view of this promotes a 'simple' notion of balance and harmony, an alternative interpretation of the words can be that one has to be at peace and in balance without undue emotional stress to remain open and in harmony with the surroundings.

The second appearance is “君子之中庸也, 君子而时中”, which can be translated as 'respectable men practice Zhong-Yong and they do so according to the specific situations they are in'. While this is typically seen as a reinforcement of balance and harmony, an extended interpretation is that every situation is unique and circumstances can evolve in new and unexpected ways that require a position of harmony and balance that is adapted to the changing conditions.

The third appearance is “舜其大知也与. 舜好问而好察迩言, 隐恶而扬善, 执其两端, 用其中 于民. 其斯以为舜乎”, which can be translated as 'the sage-king Shun indeed was greatly wise! Shun loved to ask people and study their words though they might be shallow. He discarded the bad parts in them and promoted the good parts. He took hold of extremes and chose something in between them to be used in his government of the people. It was by this that he was Shun'. This passage can be broadly interpreted as advice that good top managers (e.g., Shun) listen to many sources including people at the bottom of the organization to gain diverse insights that when analyzed and synthesized can capture best practices, ideas, and solutions for better outcomes and results. In Shun's way of balancing, the 'analysis' part is that he distinguishes good and bad parts in people's words, and the 'synthesis' part is that he combines the good parts of different people's words while discarding their bad parts.

The fourth appearance is “故君子和而不流, 中立而不倚”, which can be translated as “thus respectable men maintain harmony but do not simply follow others without thinking. They stand in the middle without leaning to either side'. While this can be seen as mere enforcement of balance and harmony, an alternative interpretation sees advice that good leaders, while in balance, do not 'just' pursue the given road, but consider updated information to find a better way through analysis and synthesis of diverse insights. 
Zhong-Yong or 'Ying-Yang balancing' is more often than not associated with a harmonious oscillation or circulation between extreme positions of interdependent opposites guided by mechanisms where the opposite elements always are "partially complementary and partially conflicting" (Li P., 2016: 58). This common interpretation is often supported or illustrated by the aesthetically beautiful Ying-Yang symbol extrapolated into appealing depictions of harmonious circular process-oriented mechanisms that invite a ratio-based balancing between extreme opposite 'physical' phenomena that can somehow be measured. We were ourselves led down this path of construing neat harmonious movements between the paradoxical top-down and bottomup processes of strategy-making in organizations (Andersen, Hallin, \& Li, 2014). However, we realized the shortcomings of this approach to capture the complexity of real organizations where many diverse processes in different parts of the organization are far from synchronized but are molded in social systems constantly affected by exogenous factors beyond management control. Hence, the reality we observe often appears messy, unruly, and abrupt in the way new paths evolve often in unexpected (even unharmonious) sprints. So, we suggest an alternative interpretation of Zhong Young that relates to this environmental context.

So, based on the four excerpts of Zhong-Yong we argue that executives should retain balance to keep an open mind in unique situations that may evolve in unexpected ways depending on circumstance and listen to multiple sources including the bottom to gain diverse insights for developing new solutions rather than pursuing the given road. This interpretation takes us away from a holistic process-oriented perspective between paradoxical extremes (Chen, 2002) that invites percentage division between seemingly opposing processes (e.g., Li, P., 2014, 2016), alternative strategy-making modes (e.g., Hart, 1992) or resource-committing decisions (e.g., Burgelman and Grove, 2007). In other words, we are no longer 'just' dealing with 'physical' phenomena of related processes but with 'metaphysical' issues of comprehension linked to current information, updated insights, specialized knowledge and diverse experiences seeking to find solutions and new ways in a changing context.

The metaphysical aspects of sense-making and deliberating are not confined to a physical space or similar resource-based restrictions that in any meaningful way can be separated in percentages of specific mechanisms. The information and knowledge flows associated with these processes defy a physical presence as they mostly exist in the 'cloud' as bits of communication between individuals dispersed across many brains within and outside the organization. They are also in principle infinite in circumscription but can possibly be influenced by the external environment and enhanced by specific features of the organizational context.

In our view, the common ratio-based understanding of Zhong-Yong is based on a conventional understanding of Ying-Yang balanced positions that should be somewhere in between two opposite poles where the in-between position is determined by the situation, e.g., time, place, issue, who are involved, etc. We argue, the alternative interpretation of Zhong-Yong and particularly the Shun's way of balancing, is not simply about finding an appropriate degreeposition between opposite extremes but rather relates to finding alternative solution through analysis of diverse insight and synthesis between them to find better solutions considering the good parts of opposite views.

The subsequent development of Zhong-Yong has not necessarily made the concept clearer, and 'in practice zhongyong means countless things: moderation, rectitude, objectivity, sincerity, honesty, truthfulness, propriety, equilibrium, and lack of prejudice'; but even though it has been transformed over time, 'it is still the substance of learning, the source of values, and the social 
code of the Chinese' (Encyclopedia Britannica. In short, there are some distinct values associated with the Zhong-Yong concept that influence the behavior of top management as well as employees and lower-level managers at the bottom of the organization. Looking at these values only two of them (moderation and equilibrium) seem related to the view of balance and harmony whereas the other seven (rectitude, objectivity, sincerity, honesty, truthfulness, propriety and lack of prejudice) speak to the new interpretation where information and knowledge acquisition by top management is essential for good analysis and synthesis.

This is commensurate with Duncan's (1976) work pointing to the necessity of developing an organizational climate that supports innovation and Gibson and Birkinshaw (2004) emphasis on a particular organizational context to facilitate ambidexterity. So, a reinterpretation of ZhongYong (i.e., Shun) provides us with the following prescriptive insights from the life-wisdom of Eastern philosophy: ${ }^{2}$

First, top management (e.g., Shun as the sage-king) must listen to various views and opinions also from employees and low-level managers at the bottom of the organization to be better informed about complex issues.

Second, top management must analyze the diverse elements of the various views and opinions they collect and synthesize by taking the good from the bad to find smarter solutions and make decisions with better outcomes.

Third, abiding by a set of (more or less) cohesive values help top managers be open and receptive to information and insights from low-level organizational members and enhancing unbiased information.

In the next subsection, we discuss this alternative solution developed by connecting Chinese philosophy and Western perspectives to better understand the particular paradox associated with the top-down and bottom-up processes in strategy-making.

We first present a contemporary strategy-making model based on the extant management literature and link it to the new interpretation of Zhong-Yong by developing a number of propositions that incorporate the 'Analysis plus Synthesis' solution to reconcile the seemingly opposing top-down and bottom-up perspectives.

\section{Application of the 'Analysis plus Synthesis' Solution to the Paradox of Top-Down and Bottom-Up Processes in Strategy Making}

Schendel and Hofer (1979) are often acknowledged as the founders of the strategic management process model (Rabin, Miller and Hildreth, 2000). Strategic management is presented as an analytical process of organizational renewal and growth to guide the organization. The paradigm

\footnotetext{
${ }^{2}$ Many contemporary management scholars in the West have studied various aspects of this, e.g., Dutton (1993) on 'selling issues' and lack of top management receptiveness, Simons (1990, 1991, 1994) on 'interactive controls' where top management solicits updated information from lower-level managers, Burgelman \& Grove (1996) and Grove (1996) on the importance of recognizing strategic initiatives at the bottom of the organization, etc. Many others also considered the importance of organizational values, e.g., Simons (1995) on 'core values'. There is also a psychology literature explaining how 'power' can limit the receptiveness of leaders (Blader and Chen, 2012). And various articles and books describing how (otherwise intelligent) executives make 'stupid' decisions due to overconfidence and overreliance on their own belief structure or 'dominant logic' (Reitzig and Maciejovsky, 2014; Reitzig and Sorenson, 2013).
} 
was built on substantive contributions by 19 academics and practitioners at a foundational conference on business policy and planning (Schendel and Hofer, 1979). They strategy-making process follows sequential steps of goal formulation, environmental analysis, strategy formulation, evaluation, implementation, and strategic control, which is consistent with other strategic planning paradigms (e.g., Grant and King, 1982; Greenwood and Thomas, 1981). Andrews' (1971; 1987) distinction between formulation with identification of opportunities/risks and subsequent application of resources to implement the strategy was retained in the framework. Hence, the strategy process is essentially concerned with strategic choice and implementation where the basic steps of mission and goal setting, external and internal analyses, selection of strategies, implementation and control are found in most contemporary strategy textbooks (e.g., Hill and Jones, 2001).

We capture top-down strategy-making process in four sequential activity steps comprised by: (1) Plan - defining purpose, analyze, set direction, outline actions (2) Implement - communicate direction and carry out (execute) the planned actions, (3) Control-register outcomes from ongoing activities and compare with planned outcomes, and (4) Reflect - assess discrepancies between intent and realized outcomes as updated input for the next planning cycle. ${ }^{3}$

Bower (1970) is often considered the original proponent of bottom-up resource committing decisions as a basic source of strategy-making. The importance of dispersed decision power in strategy-making was addressed by Mintzberg's $(1973 ; 1978)$ in conceptualizations of intended and emergent strategies. Similar ideas were explored by Burgelman (1983b; 2002) in empirical studies of corporate ventures that eventually could become part of the formal corporate strategy over time outlining an evolutionary perspective. The so-called Bower-Burgelman (BB) process model (Bower and Doz, 1979; Burgelman, 1996) outlines how autonomous initiatives can form the corporate strategy. The model introduces autonomous strategic behaviours as an essential source for new market opportunities developed from the bottom-up. The lower-level managers are entrepreneurial participants that support new business activities and convince top management about their strategic potential. All strategic renewal emerges from initiatives taken by entrepreneurial individuals within the organization. This bottom-up driven process depends on a conductive structural context established by top management. The evolutionary lens reflected in the BB model largely reduces the role of top management as being responsible for structuring the organization and signing off on the formal corporate strategy, whereas new conceptual ideas derive from bottom-up processes around engaged entrepreneurial managers.

Hence, we capture bottom-up strategy-making as consisting of many short-cycled learning processes carried out at lower hierarchical levels in the organization.

Top-down strategy-making starts with developing a mission statement with a fundamental purpose, long-term goals, and behavioral guidelines based on leadership aims and analysis of alternative strategic options. Then the aspirations are communicated to employees and managers at different levels to specify the intended strategic aims as the basis for more detailed action plans to be executed throughout the organization. Once the planned actions have been implemented the resulting outcomes are compared to the initial goals as an evaluation of the ability to execute the

\footnotetext{
${ }^{3}(3)+(4)=$ strategic control process.
} 
plans where reflection may cause a re-evaluation of the strategy that can then influence the next planning cycle (Figure 1).

We do not ascribe particular steps to the bottom-up strategy-making but ascribe them to comprise common learning cycles (Conceptualize $\rightarrow$ Test $\rightarrow$ Experience $\rightarrow$ Reflection) (Kolb and Fry, 1974) or continuous improvement processes (Plan $\rightarrow$ Do $\rightarrow$ Check $\rightarrow$ Adjust) (Deming, 1986). Therefore, the many initiatives taken at the bottom of the organization by entrepreneurial employees and lower-level managers try out new business propositions and generate updated insights that may turn into future strategic business activities (see Figure 1).

- Insert Figure 1 about here -

In practice, the observable strategy-making activities are messy and often unstructured constituting a mixture of formally planned processes and emergent initiatives taken at different times in different parts of the organization as opportunities arise and conditions change. Hence, emergence can be both top-down driven and managed by top management (Quinn, 1976) but can also be a bottom-up driven process where entrepreneurial individuals within the organization take initiatives to exploit opportunities or try out new ventures (Burgelman, 1983a). Similarly, strategic intent can also be supported by bottom-up driven activities when the new initiatives taken by lower-level employees and managers are aligned with the official corporate strategy but can also be top-driven as implemented activities from the strategic planning process.

In view of the new interpretation of Zhong-Yong, it is important to note that the many initiatives taken in the bottom-up strategy-making process generate new updated insights about market opportunities and business solutions that might work, which should be of general interest to top management. Therefore, the Zhong-Yong (Shun) perspective of collecting information and listening to diverse insights from the bottom is highly relevant.

The bottom-up strategy-making process see strategy as deriving from initiatives taken by many individual decision-makers located in different operational functions throughout the organization. In a decentralized decision structure low-level managers and employees have some leeway to act within their areas of responsibility and can voice their opinions about current experiences and insights gathered from day-to-day operations (e.g., Child and McGrath, 2001; Volberda, 1996). To the extent local organizational actors can respond and take initiatives in view of ongoing changes in the task environment they can observe relatively quickly what may work and what not due to the relatively quick feedback obtained from the short-looped learning cycles. These experiential insights obtained by employees and lower-level managers constitute updated information about current changes in the business environment (e.g., Hallin, Andersen and Tveterås, 2017).

The availability of updated environmental information represents a genuine opportunity for top managers to access where they typically would get their information from colleagues and peers in the industry and internal management reports. If top managers gain the majority of their information from sources that are distant both in time and space from current business activities, they may increasingly develop a biased conceptual understanding of the organization's competitive environment. These cognitive biases can escalate if the executives remain distant from experiential insights obtained in the daily operations over extended periods of time (e.g., Bazerman and Moore, 2009; Bettis and Prahalad, 1995). 
Hence, top management should be conscious about the many short-cycled learning loops generated from individual actions in different parts of the organization among employees and lower-level managers. By consciously seeking experiential insights from different organizational members located at the bottom of the organization the ongoing analyses of top management can be fueled by relevant updated information as the basis for further scrutiny and analytical treatment.

This is exactly what Zhong-Yong (Shun) suggests: Top management must listen to various views and opinions also from employees and low-level managers at the bottom of the organization to be better informed about complex issues. Hence,

Proposition 1: Organizations where top management consciously listens to the diverse insights provided by employees and lower-level managers are better informed about current business conditions and viable strategic opportunities.

When top management is open to receive information and encourages communication from lower-level managers and employees in different parts of the organization it will broaden the executive discussions and provide more nuanced views to the strategic deliberations. The exposure to diverse views and insights can create a deeper understanding that can be reconciled through analytical interpretations. The short-cycled learning loops associated with the fast responses taken by lower-level managers and employees to deal with changing conditions in their task environments can explore different approaches and solutions to the changing requirements of the competitive environment. These dispersed initiatives can also be interpreted as local experimentation that may uncover new business opportunities that eventually can become future strategic businesses (Burgelman, 1996; Burgelman and Grove, 1996, 2007).

The strategic considerations carried out by top management must be informed by the updated experiential insights obtained from the various initiatives taken by employees and lower-level managers at the bottom of the organization close to operational reality of the business. The exchange of information and updated insights from among individuals in all parts and levels of the organization can enable top management with the opportunity to systematically list and analyze the various perspectives and identify those approaches that seem to work while learning from those that failed. This can form a basis for extracting the best innovative approaches and collaborative learning solutions as for the organization as a whole.

This is exactly what Zhong-Yong suggests: Top management must analyze the diverse elements of various views, insights and opinions they receive and synthesize it by taking the best elements to generate smarter solutions and make better decisions. Hence,

Proposition 2: Organizations where top management obtains and exchanges insights for comparative analysis and synthesis can extract best practices and good business ideas that generate better solutions to deal with changing conditions.

Open communication and information exchange relies on a particular decentralized structure where individuals are given sufficient leeway to act and respond combined with encouragement to share information and speak up about concerns without fear of potential repercussions. In other words, it requires a set of norms with mutually accepted behaviors guided by explicit core values enacted by top management through practice (Andersen, 2017; Mintzberg, Simons and Basu, 2002; Simons, 1995). The way individuals operate within an organization, how they interact with each other, and their willingness to openly share relevant information is influenced 
by internal structures, routines, rules and norms as basic guidelines for accepted behavior. So, it is important that people interact with each other in particular ways, which is influenced by the prevailing values, beliefs and commonly accepted norms imposed by top management (Christakis and Fowler, 2009; Schein, 2010).

The way individuals interact in a human network can form a collective intelligence with nonlinear emergent properties that can innovate with creative responses to unruly changing conditions (Kaufman, 1993). Top management can exploit this knowledge embedded among many people at the bottom by maintaining an open mind and listening to many diverse perspectives. The related creative innovation processes also derive from the way people are allowed and encouraged to act and interact with each other rather than arising from the mind of single individuals (Csikszentmihalyi, 1996). So, the ability to generate innovative solutions and valuable new insights is a function of the particular organizational setting and surroundings that stimulate open interaction among individuals sharing knowledge and updated insights where the prevailing norms support exchange of information (Richerson and Boyd, 2005).

This is really captured in the wisdom of Zhong-Yong: abiding by a set of deeply embedded values will help top managers be open and receptive to diverse information and insights from the bottom of the organization and will encourage organizational members to share unbiased information and generate new creative solutions. Hence,

Proposition 3: Organizations where top management promote values that reflect rectitude, objectivity, sincerity, honesty, truthfulness, propriety and lack of prejudice will create a climate that is conducive for open exchange of information without conscious biases.

In the following section we summarize our general discourse and discuss the implications of the propositions inspired by our reinterpretation of Zhong-Yong. We further consider the potential contribution of Eastern philosophy to Western management studies in the context of managing top-down and bottom-up strategy-making processes in organizations.

\section{CONCLUDING REMARKS}

Above, we have tried to demonstrate that there is little basis for asserting superiority of Chinese way of thinking, in the name of 'Yin-Yang balancing'; in contrast, we can generate better ideas by connecting Eastern and Western perspectives on paradox management.

The 'Yin-Yang balancing' approach provides plausible recommendations to pursue the middleground between extremes in most affairs and instill a sense of harmony where opposing perspectives can interact over time and space with countervailing influences. The aesthetic beauty of the Yin-Yang symbol can be used to extrapolate harmonious oscillating exchanges between processes whereby opposing forces or tensions interact with each other in a dynamic orderly manner (e.g., Andersen et al., 2014; Li P., 2016). However, in most cases this does not reflect the messy reality observed in the exogenous business context where contemporary (and historical) organizations operate(d). The underlying pressures may be multidimensional, abrupt, messy, and 'all over the place' rather than reflecting orderly binary processes as the Ying-Yan symbol suggests. We contend that in many circumstances it does not seem to provide deeper understanding of the phenomena to be managed or give useful prescriptions compared to what is already conveyed in Western management studies. For example, the 'Yin-Yang balancing' approach suggests that opposing tensions should oscillate within a certain range across the middle-ground between the 
extreme positions. But this way of partitioning different resources or processes is not fundamentally different from those suggested in various (strategic) management studies (e.g., Hart, 1992; Burgelman and Grove, 2007).

In many situations adopting positions along the middle can be meaningless, because it requires that you deal with something finite and measurable, or they might even be misleading. For example, the classical study of the solution to the paradox between concern for production of results and concern for people (Blake and Mouton, 1964) is clearly not commensurate with and in between solutions (e.g., 5-5 in Figure 2), but rather demands a position where tensions are imposed equally (9-9 in Figure 2). This insight of older date from Western management scholarship seemingly gains little from 'Yin-Yang balancing', which rather seems to confuse the need for analytical synthesis to reconcile the two opposing concerns. Similarly, the conundrum between central planning and decentralized decision-making is not resolved by assuming middle grounds between the two, but by integrating both processes at a high level as suggested by theoretical reasoning and empirical evidence (Andersen, 2004). In fact, western scholarship has already pointed these concerns out by suggesting that the resolution to many paradoxes must be sought in the "Synthesis Area" rather than along the "Trade-off line" between the two opposing pressures that cause the paradoxical tension (De Witt and Meyer, 2004).

\section{- Insert Figure 2 about here -}

The 'simple' prescription to stay within the outer limits of extreme values only applies to concepts that can be meaningfully measured. The problem then arises when you deal with the exchange of creative insights and new knowledge that defy physical constraint but where such information processing nonetheless is essential for the organization's ability to respond and adapt to disruptive environments. A good framework must be able to make prescriptions beyond measurable situations or phenomena identified by measurable symptoms. This is where the new interpretation of the Eastern philosophy and wisdom of Zhong-Yong can provide useful guidance on the importance of listening to updated information from the bottom supported by core values that provide an organizational climate conducive for effective exchange of information.

While this might sound like a mundane realization, it is a deep insight that few top managers in the West can master, nor is it widely prescribed by mainstream Western management studies. The status for top management receptiveness is rather dismal as Dutton (1993: 339) concludes "that conditions in organizations put decision-makers 'on automatic' in their diagnosis of strategic issues" with negative consequences for the quality of decision outcomes. Our libraries are filled with books that account for the many failures otherwise 'smart' executives have made because they rely on their own cognition (e.g., Bazerman and Moore, 2009; Finkelstein, 2003; Finkelstein, Whitehead and Campbell, 2008; Rosenzweig, 2008). The concept of the 'dominant logic' and its ability to deceive top managers that venture into new business territory or try to respond to unknown conditions without consulting diverse insight is well known (Prahalad and Bettis, 1986; Bettis and Prahalad 1995).

Hence, much Western scholarship show the importance of listening to diverse views to gain better understanding and avoid fundamental biases (e.g., Quinn, 1980; Eisenhardt, 1989) while prescribing the need for updates insights (e.g., Simons, 1990, 1991, 1994). Yet, very few studies point directly to the importance of core values to back these principles, i.e., it remains very difficult to manage in practice. Hence, the deep insights offered by Zhong-Yong (Shun) can be highly supportive. Hence, it is probably not a coincidence that one of the most innovative and successful 
companies has its root in China with its success widely ascribed to the leader's strong belief in traditional Chinese philosophy (e.g., Lewin, Välikangas and Chen, 2017; Sun, Cao, Li and Li, 2017). It is also noteworthy that a new stream of leadership studies consider the effects of humility (vs. hubris) and information sharing spearheaded by a cadre of young Eastern or Chinese scholars (e.g., Lam, Huang and Chan, 2015; Li and Tang, 2010; Ou et al., 2014; Ou, Waldman and Peterson, 2018; Tang, Qian, Chen and Shen, 2015). This research with an emphasis on leadership values is clearly inspired by ancient Chinese philosophy and promises to provide new important insights. 


\section{REFERENCES}

Amason, A. C. 1996. 'Distinguishing the effects of functional and dysfunctional conflict on strategic decision making: resolving a paradox for top management teams'. Academy of management journal, 39(1): 123-148.

Andersen, T.J. 2004. Integrating decentralized strategy making and strategic planning processes in dynamic environments. Journal of Management Studies, 41(8): 1271-1299.

Andersen, T. J. 2017. Corporate responsible behavior in multinational enterprise. International Journal of Organizational Analysis, 25(3): 1-21.

Andrews, K. 1971. The concept of strategy. Homewood, IL: Irwin.

Ansoff, H. I. 1988. The new corporate strategy. New York, NY: Wiley.

Barkema, H. G., Chen, X. P., George, G., Luo, Y. and Tsui, A. S. 2015. 'West meets East: new concepts and theories'. Academy of Management Journal, 58(2): 460-479.

Bartlett, C. A. and Ghoshal, S. 1989. Managing across borders: the transnational solution. Boston, MA: Harvard Business School Press.

Bartunek, J. M. and Rynes, S. L. 2014. 'Academics and practitioners are alike and unlike: the paradoxes of academic-practitioner relationships'. Journal of Management, 40(5): 1181-1201.

Bazerman, M. H. and Moore, D. A. 2009. Judgment in Managerial Decision Making $\left(7^{\text {th }}\right.$ ed.. Hoboken, NJ, John Wiley \& Son.

Bennis, W. G. and O'Toole, J. 2005. 'How business schools lost their way'. Harvard Business Review, 83(5): 96-105.

Bettis, R. A. and Prahalad, C. K. 1995. The dominant logic: Retrospective and extension. Strategic Management Journal, 16(1): 5-14

Blader, S. L. and Chen, Y. R. 2012. 'Differentiating the effects of status and power: a justice perspective'. Journal of personality and social psychology, 102(5): 994-1014.

Blake, R. and Mouton, J. 1964. The Managerial Grid: The Key to Leadership Excellence. Houston, TX: Gulf Publishing.

Bobko, P. 1985. 'Removing assumptions of bipolarity: towards variation and circularity' Academy of Management Review, 10(1): 99-108.

Bourgeois, L. J. and Brodwin, D. R. 1984. 'Strategic implementation: five approaches to an elusive phenomenon’. Strategic Management Journal, 5(3): 241-264.

Bower J. L. 1970. Managing the resource allocation process: a study of corporate planning and investment. Boston: Division of Research, Graduate School of Business Administration, Harvard University.

Bower, J. L. and Doz, I. 1979. 'Strategy formulation: a social and political view'. In D. E. Schendel \& C. W. Hofer (Eds.): Strategic Management. Boston, MA: Little Brown, 152-166.

Brady, M. and Walsh, A. 2007. 'Setting strategic direction: a top down or bottom up process?'. Business Strategy Series, 9(1): 5-11. 
Burgelman, R. A. 1983a. 'A model of the interaction of strategic behavior, corporate context, and the concept of strategy'. Academy of Management Review 8(1): 61-70.

Burgelman, R. A. 1983b. 'A Process Model of Internal Corporate Venturing in the Diversified Major Firm'. Administrative Science Quarterly, 28(2): 223-244.

Burgelman, R. A. 1996. A process model of strategic business exit: Implications for an evolutionary perspective on strategy. Strategic Management Journal, 17(S1): 193-214.

Burgelman, R. A. and Grove, A. S. 1996. Strategic dissonance. California Management Review, 38(2): 8-28.

Burgelman, R. A. and Grove, A. S. 2007. 'Let chaos reign, then rein in chaos-repeatedly: managing strategic dynamics for corporate longevity'. Strategic Management Journal, 28(10): 965-979.

Cameron, K. S. 1986. 'Effectiveness as paradox: consensus and conflict in conceptions of organizational effectiveness'. Management science, 32(5): 539-553.

Chakravarthy, B. S. 1982. 'Adaptation: a promising metaphor for strategic management'. Academy of Management Review, 7(1): 33-44.

Chandler, A. D. 1990. Scale and scope: the dynamics of industrial capitalism. Cambridge, MA: Harvard University Press.

Chen, M. J. 2002. 'Transcending paradox: the Chinese "middle way" perspective'. Asia Pacific Journal of Management, 19(2-3): 179-199.

Chen, M. J. 2008. 'Reconceptualizing the competition-cooperation relationship: a transparadox perspective'. Journal of Management Inquiry, 17(4): 288-304.

Chen, M. J. 2016. 'Competitive dynamics: Eastern roots, Western growth'. Cross Cultural \& Strategic Management, 23(4): 510-530.

Chen, M. J. and Miller, D. 2010. 'West meets East: toward an ambicultural approach to management'. Academy of Management Perspectives, 24(4): 17-24.

Chen, M. J. and Miller, D. 2011. 'The relational perspective as a business mindset: Managerial implications for East and West'. Academy of Management Perspectives, 25(3): 6-18.

Child, J. and McGrath, R. G. 2001. Organizations unfettered: Organizational form in an information-intense economy. Academy of Management Journal, 44(6): 1135-1148.

Christakis, N. A. and Fowler, J. H. 2009. Connected: The Surprising Power of Our Social Networks and How They Shape Our Lives. New York, NY: Little, Brown and Company.

Clegg, S. R. Eds.. 2002. Management and Organization Paradoxes (Vol. 9. Amsterdam: John Benjamins Publishing.

Csikszentmihalyi, M. 1996. Creativity: Flow and the Psychology of Discovery and Invention. New York, NY: Harper Perennial.

Cuonzo, M. 2014. Paradox. Cambridge, MA: MIT Press.

Daft, R. L. and Lewin, A. Y. 1990. 'Can organization studies begin to break out of the normal science straitjacket? an editorial essay’. Organization Science, 1(1): 1-9. 
Daft, R. L. and Lewin, A. Y. 1993. 'Where are the theories for the "new" organizational forms? an editorial essay'. Organization Science, 4(4): I-Vi.

Daft, R. L. and Lewin, A. Y. 2008. 'Perspective-Rigor and relevance in organization studies: idea migration and academic journal evolution'. Organization Science, 19(1): 177-183.

De Wit, B. and Meyer, R. 2001. Strategy synthesis: resolving strategy paradoxes to create competitive advantage. Stamford, Connecticut: Thomson Learning.

Demb, A. and Neubauer, F. 1992. The corporate board: confronting the paradoxes. New York: Oxford University Press.

Deming, W. E. (1986. Out of the Crisis. MIT Center for Advanced Engineering Study.

Denison, D. R., Hooijberg, R. and Quinn, R. E. 1995. 'Paradox and performance: toward a theory of behavioral complexity in managerial leadership'. Organization Science, 6(5): 524-540.

Dodd, D. and Favaro, K. 2006. 'Managing the right tension'. Harvard Business Review, 84(12): 62-74.

Duncan, R. B. 1976. 'The ambidextrous organization: designing dual structures for innovation'. In Kilmann, R. H., Pondy, L. R. and Slevin, D. P. Eds.): The management of organization: strategy and implementation, vol. 1. New York: North-Holland, 167-188.

Dutton, J. E. 1993. Interpretations on automatic: A different view of strategic issue diagnosis. Journal of Management Studies, 30(3): 339-357.

Eisenhardt, K. M. 1989. Making fast strategic decisions in high-velocity environments. Academy of Management Journal, 32(3): 543-576.

Eisenhardt, K. M. 2000. 'Paradox, spirals, ambivalence: the new language of change and pluralism'. Academy of Management Review, 25(4): 703-705.

Evans, P. 2000. 'The dualistic leader: Thriving on paradox'. In Chowdhury, S. Ed): Management 21C: Someday we'll all lead this way. London: Financial Times Prentice Hall, 66-82.

Fang, T. 2012. 'Yin Yang: a new perspective on culture'. Management and Organization Review, 8(1): $25-50$.

Farjoun, M. 2010. 'Beyond dualism: stability and change as a duality'. Academy of Management Review, 35(2): 202-225.

Finkelstein, S. 2003. Why Smart Executives Fail-And What You Can Learn From Their Mistakes. New York, NY: Penguin Books.

Finkelstein, S., Whitehead, J. and Campbell, A. 2008. Think Again: Why Good Leaders Make Bad Decisions and How to Keep it From Happening to You. Boston, MA: Harvard Business Press.

Galbraith, J. R. 1995. Designing organizations: an executive briefing. San Francisco, CA: JosseyBass.

Gibson, C. B. and Birkinshaw, J. 2004. 'The antecedents, consequences, and mediating role of organizational ambidexterity'. Academy of management Journal, 47(2): 209-226.

Gottlieb, P. 2009. The virtue of Aristotle's ethics. Cambridge: Cambridge University Press.

Grant, J. H. and King, W. R. 1982. The Logic of Strategic Planning. Boston: Little, Brown. 
Greenwood, P. and Thomas, H. 1981. 'A review of analytical models in strategic planning'. Omega, 9(4): 397-417.

Grove, A. S. 1996. Only the paranoid survive: how to exploit the crisis points that challenge every company and career. New York: Currency/Doubleday.

Gulati, R., and Garino, J. 1999. 'Get the right mix of bricks \& clicks'. Harvard Business Review, 78(3): 107-14.

Hallin, C. A., Andersen, T. J. and Tveterås, S. 2017. Harnessing the frontline employee sensing of capabilities for decision support. Decision Support Systems, 97, 104-112.

Handy. C. 1994. The age of paradox. Boston, MA: Harvard Business School Press.

Hart, S. L. 1992. 'An integrative framework for strategy-making processes'. Academy of Management Review, 17(2): 327-351.

Hart, S. and Banbury, C. 1994. 'How strategy-making processes can make a difference'. Strategic Management Journal, 15(4): 251-269.

Henrich, J., Heine, S. J. and Noranyazan, A. 2010a) 'The weirdest people in the world'. Behavioral and Brain Sciences, 33(2-3): 61-83.

Henrich, J., Heine, S. J. and Norenzayan, A. 2010b. 'Most people are not WEIRD'. Nature, 466(7302): 29-29.

Hill, C. W. L. and Jones, G. R. 2001. Strategic Management Theory: An Integrated Approach, 5th edition. Boston, MA: Houghton Mifflin.

Jahoda, G. 2016. 'On the rise and decline of "indigenous psychology"'. Culture \& Psychology, 22(2): 169-181.

Jing, R. and Van de Ven, A. 2014. 'A Y in-Yang model of organizational change: the case of CBG'. Management and Organization Review, 10(1): 55-80.

Kaufman, S. 1993. The Origins of Order: Self-Organization and Selection in Evolution. Oxford, UK: Oxford University Press.

Kieser, A., Nicolai, A. and Seidl, D. 2015. 'The practical relevance of management research: turning the debate on relevance into a rigorous scientific research program'. Academy of Management Annals, 9(1): 143-233.

Kim, Y. H., Sting, F. J. and Loch, C. H. 2014. 'Top-down, bottom-up, or both? Toward an integrative perspective on operations strategy formation'. Journal of Operations Management, 32(7): 462-474.

Kolb, D. A. and Fry, R. E. 1974. Toward an Applied Theory of Experiential Learning

Koot, W., Sabelis, I. and Ybema, S. 1996. Contradictions in context: puzzling over paradoxes in contemporary organizations. Vienna: VU University Press.

Lado, A. A., Boyd, N. G., Wright, P. and Kroll, M. 2006. 'Paradox and theorizing within the resource-based view'. Academy of Management Review, 31(1): 115-131.

Lam, C. K., Huang, X. and Chan, S. C. H. 2015. The threshold effect of participartive leadership and the role of leader information sharing. Academy of Management Journal, 58(3): 836-855. 
Leana, C. R. and Barry, B. 2000. 'Stability and change as simultaneous experiences in organizational life'. Academy of Management Review, 25(4): 753-759.

Leung, K. 2012. 'Indigenous Chinese management research: like it or not, we need it'. Management and Organization Review, 8(1): 1-5.

Lewin, A. Y., Välikangas and Chen, J. 2017. Enabling open innovation: Lessons from Haier. International Journal of Innovation Studies, 1(1): 5-19.

Lewis, M. 2000. 'Exploring paradox: toward a more comprehensive guide'. Academy of Management Review, 25(4): 760-776.

Li, J. and Tang, Y. 2010. CEO hybris and firm risk taking in China: The moderating role of managerial discretion. Academy of Management Journal, 53(1): 45-68.

Li, P. P. 2014. 'The unique value of Yin-Yang balancing: a critical response'. Management and Organization Review, 10(2): 321-332.

Li, P. P. 2016. 'Global implications of the indigenous epistemological system from the East: how to apply Yin-Yang balancing to paradox management'. Cross Cultural \& Strategic Management, 23(1): 42-77.

Li, P. P., Leung, K., Chen, C. C. and Luo, J. D. 2012. 'Indigenous research on Chinese management: What and how'. Management and Organization Review, 8(1): 7-24.

Li, P. P., Li, Y. and Liu, H. 2012. 'The exploration-exploitation link reframed from paradox into duality’. Working Paper, Copenhagen Business School.

Li, P. P., Sekiguchi, T. and Zhou, K. 2016. 'The emerging research on indigenous management in Asia'. Asia Pacific Journal of Management, 33(3): 583-594.

Li, X. 2014. 'Can Yin-Yang guide Chinese indigenous management research?'. Management and Organization Review, 10(1): 7-27.

Li, X. 2016. 'The danger of Chinese exceptionalism'. Management and Organization Review, 12(4): 815-816.

Li, X. 2018. Zhong-Yong as dynamic balancing between Yin-Yang opposites. Cross Cultural \& Strategic Management, 25(2): 375-379.

$\mathrm{Li}, \mathrm{X}$. and Ma, L. forthcoming. 'Chinese management research needs more self-confidence but not over-confidence', Asia Pacific Journal of Management, https://doi.org/10.1007/s1049

Lin, D., Lu, J., Li, P. P. and Liu, X. 2015. 'Balancing formality and informality in business exchanges as a duality: a comparative case study of returnee and local entrepreneurs in China'. Management and Organization Review, 11(2): 315-342.

Losin, P. 1987. 'Aristotle's doctrine of the mean'. History of Philosophy Quarterly, 4(3): 329-341.

March, J. G. 1991. 'Exploration and exploitation in organizational learning'. Organization Science, 2(1): 71-87.

March, J. G. 2010. The ambiguities of experience. Ithaca, NY: Cornell University Press.

Miller, D. 1990. The Icarus paradox: how excellent organizations can bring about their own downfall. New York: Haper Business. 
Mintzberg, H. 1978. 'Patterns in strategy formation'. Management Science, 24(9): 934-948.

Mintzberg, H. and Waters, J. 1985. 'Of strategies, deliberate and emergent'. Strategic Management Journal, 6(3): 257-272.

Mintzberg, H., Simons, R. and Basu, K. 2002. Beyond selfishness. MIT Sloan Management Review, 44(1): 67-74.

Mitroff, I. I. 1983. 'Archetypal social systems analysis: on the deeper structure of human systems'. Academy of Management Review, 8(3): 387-397.

Mom, T. J., Van Den Bosch, F. A. and Volberda, H. W. 2007. Investigating managers' exploration and exploitation activities: The influence of top-down, bottom-up, and horizontal knowledge inflows. Journal of management studies, 44(6): 910-931.

Nagji, B. and Tuff, G. 2012. 'Managing your innovation portfolio'. Harvard Business Review, 90(5): 66-74.

Nonaka, I. 1988. 'Self-renewal of the Japanese firm and the human resource strategy'. Human Resource Management, 27(1): 45-62.

O'Reilly, C. A. and Tushman, M. L. 2013. 'Organizational ambidexterity: past, present, and future'. Academy of Management Perspectives, 27(4): 324-338.

Ou, A. Y., Tsui, A. S., Kinicki, A. J., Waldman, D. A., Xiao, Z. and Song, L. J. 2014. Humble Chief Executive Officers' Connections to Top Management Team Integration and Middle Managers' Responses. Administrative Science Quarterly, 59(1): 34-72.

Ou, A. Y., Waldman, D. A. and Peterson, S. J. 2018. Do humble CEOs matter? An examination of CEO humility and firm outcomes. Journal of Management, 44(3): 1147-1173.

Peng, M. W. 2005. 'Perspectives - from China strategy to global strategy'. Asia Pacific Journal of Management, 22(2): 123-141.

Perrow, C. 1977. 'The bureaucratic paradox: the efficient organization centralizes in order to decentralize'. Organizational Dynamics, 5(4): 3-14.

Peters, T. and Waterman, H. 1982. In search of excellence. New York: Harper and Row.

Poole, M.S. and Van de Ven, A.H. 1989. 'Using paradox to build management and organisational theories'. Academy of Management Review, 14(4): 562-578.

Prahalad, C. K. and Bettis, R. A. 1986. 'The dominant logic: A new linkage between diversity and performance'. Strategic Management Journal, 7(6): 485-501.

Quinn, J. B. 1980. Strategies for Change: Logical Incrementalism. Burr Ridge, IL: Irwin Professional Publishing.

Quine, W. V. 1976. The ways of paradox, and other essays. Boston, MA: Harvard University Press.

Quinn, R.E. and Cameron, K.S. Eds) (1988. Paradox and transformation: towards a theory of change in organization and management. Cambridge, MA: Balinger Publishing.

Rabin, J., Miller, G. J. and Hildreth, W. B. 2000. Handbook of strategic management, 2nd edition. Public administration and public policy 79. New York: Marcel Dekker. 
Reitzig, M. and Sorenson, O. 2013. 'Biases in the selection stage of bottom-up strategy formulation'. Strategic Management Journal, 34(7): 782-799.

Reitzig, M. and Maciejovsky, B. 2014. 'Corporate hierarchy and vertical information flow inside the firm: a behavioral view’. Strategic Management Journal, 36(13): 1979-1999.

Richerson, P. and Boyd, R. 2005. Not by Genes Alone: How Culture Transformed Human Evolution. Chicago, IL: University of Chicago Press.

Rosenzweig, P. 2008. The halo effect: how managers let themselves be deceived. London, UK: Pocket Books.

Schad, J., Lewis, M. W., Raisch, S. and Smith, W. K. 2016. 'Paradox research in management science: looking back to move forward'. Academy of Management Annals, 10(1): 5-64.

Schein, E. H. 2010. Organizational Culture and Leadership (Vol. 2. Hoboken, NJ: John Wiley \& Sons.

Schendel, D. E. and Hofer, C. W. 1979. Strategic management: a new view of business policy and planning. Boston: Little, Brown and Company.

Seo, M. G. and Creed, W. D. 2002. 'Institutional contradictions, praxis, and institutional change: a dialectical perspective'. Academy of Management Review, 27(2): 222-247.

Siggelkow, N. 2007. 'Persuasion with case studies'. Academy of Management Journal, 50(1): 2024.

Simons, R. 1990. The role of management control systems in creating competitive advantage: new perspectives. Accounting, Organizations and Society, 15(1-2): 127-143.

Simons, R. 1991. Strategic orientation and top management attention to control systems. Strategic Management Journal, 12(1): 49-62.

Simons, R. 1994. How new top managers use control systems as levers of strategic renewal. Strategic Management Journal, 15(3): 169-189.

Simons, R. 1995. Control in an age of empowerment. Harvard Business Review, 73(2): 80-88.

Slaatte, H. A. 1986. The pertinence of the paradox. New York: Humanities Press.

Smith, K. K. and Berg, D. N. 1987. Paradoxes of group life: understanding conflict, paralysis, and movement in group dynamics. San Francisco, CA: Jossey-Bass.

Smith, W. 2014. 'Dynamic decision making: a model of senior leaders managing strategic paradoxes'. Academy of Management Journal, 57(6): 1592-1623.

Smith, W. K., Binns, A. and Tushman, M. L. 2010. 'Complex business models: managing strategic paradoxes simultaneously'. Long Range Planning, 43(2-3): 448-461.

Smith, W. K. and Lewis, M. W. 2011. 'Toward a theory of paradox: a dynamic equilibrium model of organizing'. Academy of management Review, 36(2): 381-403.

Smith, W. K. and Tushman, M. L. 2005. 'Managing strategic contradictions: a top management model for managing innovation streams'. Organization Science, 16(5): 522-536.

Stroh, P., \& Miller, W. W. 1994. 'Learning to thrive on paradox'. Training and Development, 48(9): 28-39. 
Sun, X., Cao, Y., Li, S. and Li, X. 2017. Building a global responsive organization: The case of the Hair Group, in Andersen, T. J. ed.) The Responsive Global Organization: New Insights from Global Strategy and International Business: 149-168. Emerald Publishing, London, UK.

Sundaramurthy, C. and Lewis, M. 2003. 'Control and collaboration: paradoxes of governance'. Academy of Management Review, 28(3): 397-415.

Tang, Y., Qian, C., Chen, G. and Shen, R. 2015. How CEO hybris affects corporate social (ir)responsibility. Strategic Management Journal, 36(9): 1338-1357.

Tushman, M. L. and O’Reilly, C. A. 1996. 'Ambidextrous organizations: managing evolutionary and revolutionary change'. California Management Review, 38(4): 8-29.

Van de Ven, A. 1983. 'Book review: In search of excellence: lessons from America's best run companies. Administrative Science Quarterly, 28(3): 621-624.

Vermeulen, F. 2005. 'On rigor and relevance: fostering dialectic progress in management research'. Academy of Management Journal, 48(6): 978-982.

Volberda, H. W. 1996. Toward the flexible form: How to remain vital in hypercompetitive environments. Organizarion Science, 7(4): 359-374.

Andersen, T. J., Hallin, C. A., \& Li, X.. 2014. An integrative model of dynamic strategy-making: A yin-yang perspective of central and peripheral mechanisms in (global) strategy formation. Working paper, Center for Global Strategic Responsiveness, Copenhagen Business School.

Witesman, E. M. and Wise, C. R. 2009. 'The centralization/decentralization paradox in civil service reform: how government structure affects democratic training of civil servants'. Public Administration Review, 69(1): 116-127.

Zhang, Y., Waldman, D. A., Han, Y. L. and Li, X. B. 2015. 'Paradoxical leader behaviors in people management: antecedents and consequences'. Academy of Management Journal, 58(2): 538566.

Zheng, X., Li, N., Harris, T. B. and Liao, H. 2017. 'Unspoken yet understood: an introduction and initial framework of subordinates' moqi with supervisors'. Journal of Management, https://doi.org/10.1177/0149206316687642 
Figure 1. A Model of Top-down and Bottom-up Strategy-Making Processes

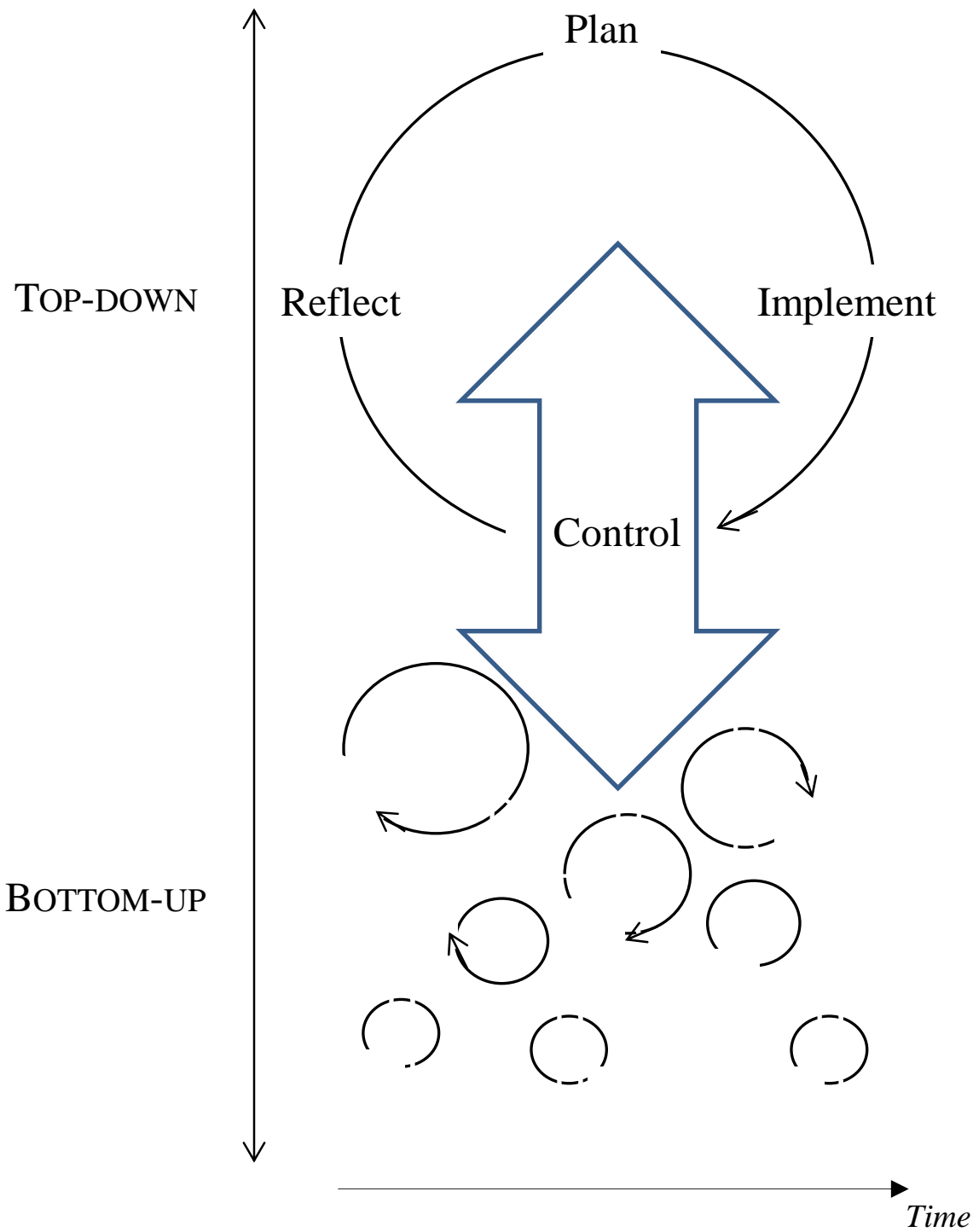


Figure 2. An Overview: Alternative Dichotomous Choices - Three Illustrative Examples

The Choice Between Concern for People and Concern for Production

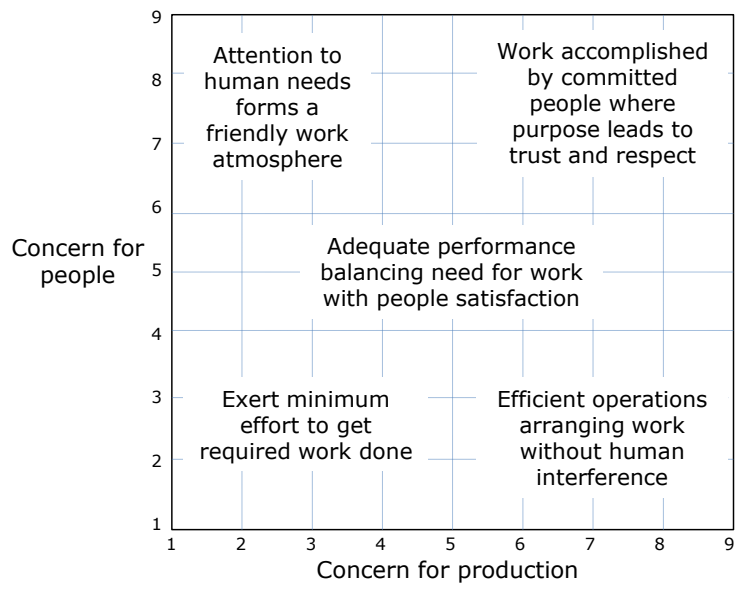

Inspired by: Blake, R. and Mouton, J. (1964)

The Choice Between Central Planning and Decentralized Decision-Making

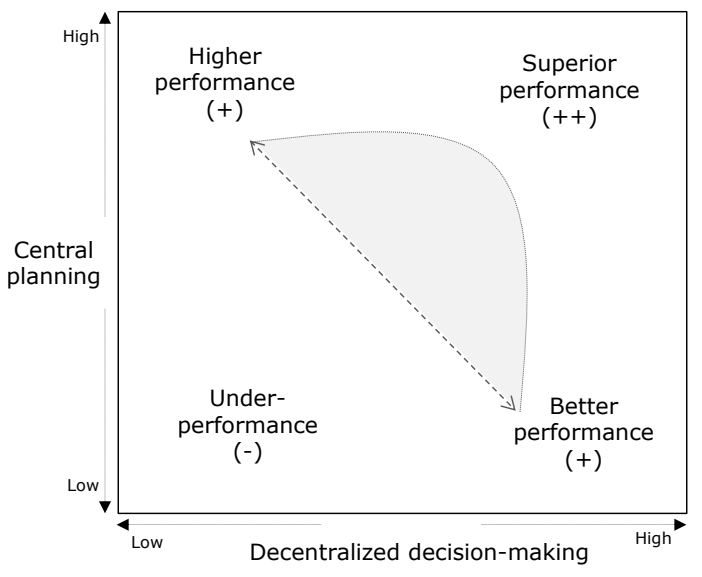

Inspired by: Andersen (2004).

The Choice Between Pressure for A and Pressure for B

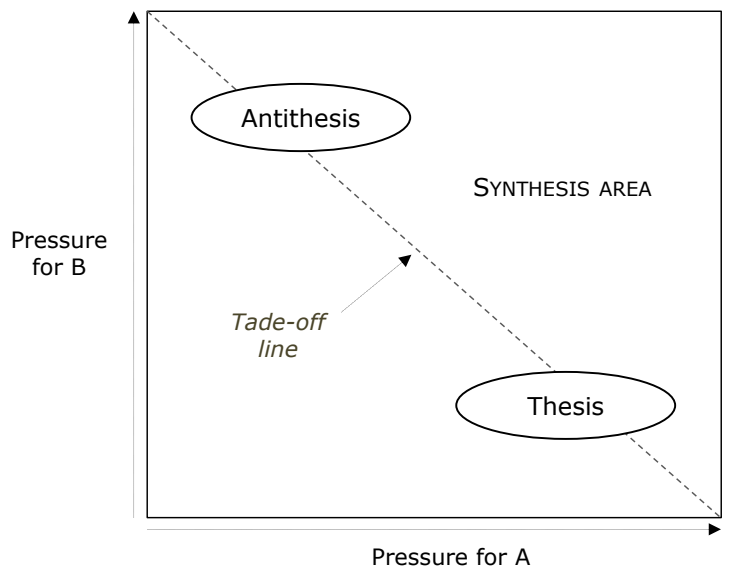

Inspired by: De Wit and Meyer (2004). 